\title{
Pembakaran Premixed Minyak Nabati pada Bunsen Burner Type Silinder
}

\author{
Syamsul Bahri La Muhaya, ING. Wardana, Denny Widhiyanuriyawan \\ Teknik Mesin Universitas Brawijaya Malang, MT Haryono 167, Malang 65145, \\ Indonesia \\ Phone : +62-341-587710, fax : +62-341-551430 \\ E-mail :syamsulbahri_lamuhaya@yahoo.co.id
}

\begin{abstract}
In the premixed combustion wave propagation combustion occurs is called the flame front. Premixed flame will propagate at the speed of moving towards the reactants unique. If the speed of the reactants is equal to the speed of propagation of fire, the fire (reaction zone) will be stationary. It is necessary to follow up on the influence of equivalence ratio $(\varphi)$ varied with laminar flame speed $(S L)$ in the premixed combustion of vegetable oil (virgin coconut oil, jatropha and cotton seeds). Research using experimental (true experimental research), which is put through direct observation by the equivalence ratio $(\varphi), 1.5,1.6,1.7$ and $1.8 \mathrm{~m} / \mathrm{l}$, to determine the causal relationship. Then the results showed a pattern of fire Bunsen burner pure coconut oil with equivalence ratio $(\varphi)$, namely: $2.00,1.87,1.78$, and 1.66 , jatropha oil with equivalence ratio $(\varphi)$ are: 1.73, 1.62, 1:52, and 1:44 and seed oil kapok with equivalence ratio $(\varphi)$ are: $1.76,1.65,1: 55$, and 1:46, the richer the air the flame pattern that looks smaller and smaller until the blow off. This happens because the richer the air causes the fuel has an air excess so that the fuel (fuel) burning diffusion semakain reduced and cause combustion close to the surface of the tip of the nozzle Bunsen burner to high flame formed shorter until there blow off or extinguished.
\end{abstract}

Keywords: premixed combustion, flame premixed, laminar flame speed (SL), equivalence ratio $(\varphi)$.

\section{PENDAHULUAN}

Semakin berkurang/menipis serta dampak yang dihasilkan oleh emisi gas buang dari hasil pembakaran bahan bakar fosil yang tidak ramah terhadap lingkungan (unrenewable), maka diperlukan sumber energi alternatif baru dan terbarukan yang mampu mencukupi atau paling tidak dapat menghemat penggunaan energi dari BBM tersebut. Dengan ini menuntut upaya untuk menggunakan bahan bakar alternatif, salah satunya minyak nabati. Mengingat minyak bumi (fosil) merupakan bahan galian dari perut bumi yang sifatnya tidak dapat diperbaharui (unrenewable). Berbagai penelitian minyak nabati telah dilakukan untuk menghasilkan bahan bakar terbarukan, salah satunya adalah biodiesel yang ramah terhadap lingkungan, seperti minyak kelapa murni (Cocos nucifera),minyak jarak pagar (Jatropha curcas linneaus) dan minyak biji kapuk (Ceiba pentandra) dan lain sebagainya yang di Indonesia dapat tumbuh dengan baik, sehingga sangat potensial untuk dikembangkan.

Sedangkan pada pembakaran premixed banyak diteliti dengan berbagai perlakuan yang bertujuan untuk mengetahui perilaku kepunahan dan kecepatan api, Qiao et al., (2005), api bunsendengan open tip, Min.et al., (2011), api seluler, Groff., (1982), dan api triple, Ray.et al., (2000). Api premixed akan merambat menuju kearah reaktan dengan kecepatan unik. Jika kecepatan reaktan sama dengan kecepatan rambatan api maka api (zona reaksi) akan stasioner. Wirawan., (2014) melakukan penelitian tentang pembakaran premixed minyak nabati pada perforated burner. Hasil penelitian menunjukan bahwa minyak kelapa murni maupun hidrolisis terjadi penurunan kecepatan pembakaran $S_{L}$ api perforated dan bunsen ketika equivalence ratio $(\varphi)$ ditingkatkan Kecepatan pembakaran $S_{\llcorner}$api perforated dan bunsen minyak jarak pagar menurun secara drastis dengan kenaikan 
equivalence ratio $(\varphi)$ sedikit saja. Sedangkan pada minyak biji kapuk terjadi penurunan kecepatan pembakaran $S_{\llcorner}$api perforated dan bunsen ketika equivalence ratio $(\varphi)$ ditingkatkan. Dharma., (2013) melakukan penelitian tentang pengararuh variasi equivalence ratio terhadap karakteristik api pembakaran premixed minyak jarak pagar pada perforated burner. Didapatkan bahwa variasi equivalence ratio mempengaruhi pola api pembakaran premixed minyak jarak pagar dan udara. Dengan massa alir bahan bakar yang kosntan, penambahan maasa alir udara mempengaruhi perubahan equivalence ratio $(\varphi)$. Penambahan massa alir udara yang semakin besar akan menyebabkan defusivitas massa reaktan lebih besar dari pada difusivitas panas, sehingga api akan mengalami lift off sampai pada akhirnya api akan padam. Disamping itu, pola api memberikan informasi pembakaran mendekati sempurna atau tidak. Warna biru mengindikasikan bahwa pembakarannya mendekati sempurna, sedangkan warna kuning mengindikasikan banyak terdapat bahan bakar yang belum terbakar secara difusi dengan udara. Sidqi, (2011) melakukan penelitian tentang menginjeksikan uap minyak kapuk kedalam microcombustor dengan temperatur bervariasi. Didapatkan bahwa semakin tinggi temperatur uap minyak kapuk maka kecepatan reaksi akan meningkat, ignition delaytime dan flash point menurun, sedangkan burning rate akan meningkat. Atas dasar ini, maka perlu melakukan penelitian untuk mengetahui karakteristik kecepatan api laminer dan equivalence ratio $(\varphi)$ dengan tiga jenis minyak nabati pada pembakaran premixed (kelapa murni, jarak pagar dan biji kapuk).

\section{METODOLOGI PENELITIAN}

Metodologi penelitian ini menggunakan metodologi penelitian eksperimental (true experimental research), yaitu melalukan pengamatan langsung untuk mengetahui hubungan sebab akibat. Dalam hal ini perangkat peneitian dibuat dalam skala Laboratorium. Pada proses pembakaran premixed minyak nabati pada bunsun burner type sylinder, dengan sistem mingisi bahan bakar minyak nabati pada ketel hingga terjadi proses penguapan sampai terbentuk nyala api. Adapun skema instalasi penelitian yang digunakan terlihat seperti pada gambar 1 .

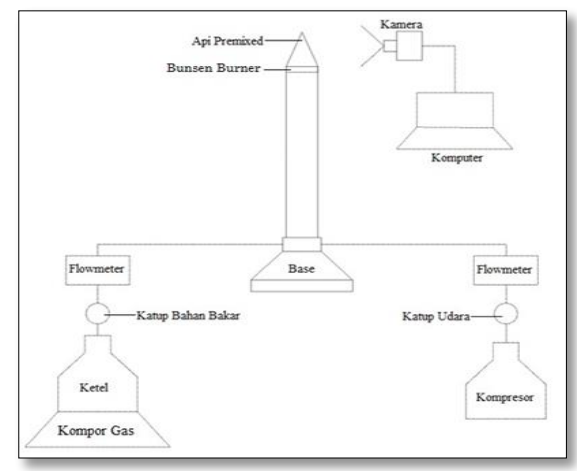

Gambar 1.Skema Instalasi

\section{HASIL DAN PEMBAHASAN}

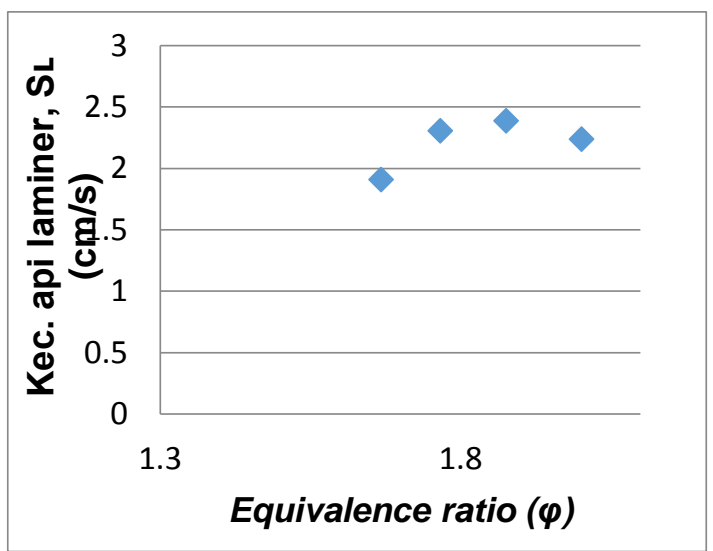

Gambar 2. Equivalence ratio $(\varphi)$ vs kecepatan api laminer (SL) minyak kelapa murni pada api bunsen burner.

Pada gambar 2-4 ditunjukkan hubungan antara equivalence ratio $(\varphi)$ terhadap kecepatan api laminer (SL) api bunsen burner masing-masing pada minyak kelapa murni, minyak jarak pagar, dan minyak biji kapuk. Sedangkan pada gambar 5 menunjukkan komparasi equivalence ratio ketiga jenis minyak nabati tersebut pada pembakaran premixed. 


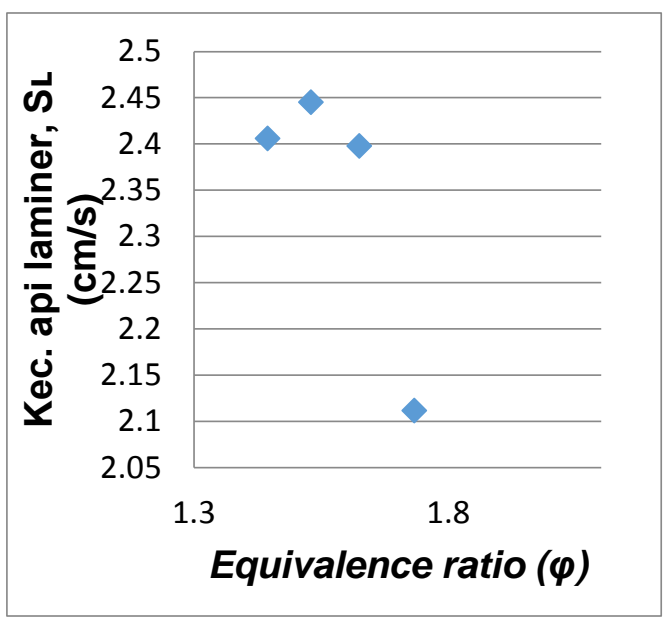

Gambar 3. Equivalence ratio $(\varphi)$ vs kecepatan api laminer (SL) minyak jarak pagar pada api bunsen burner.

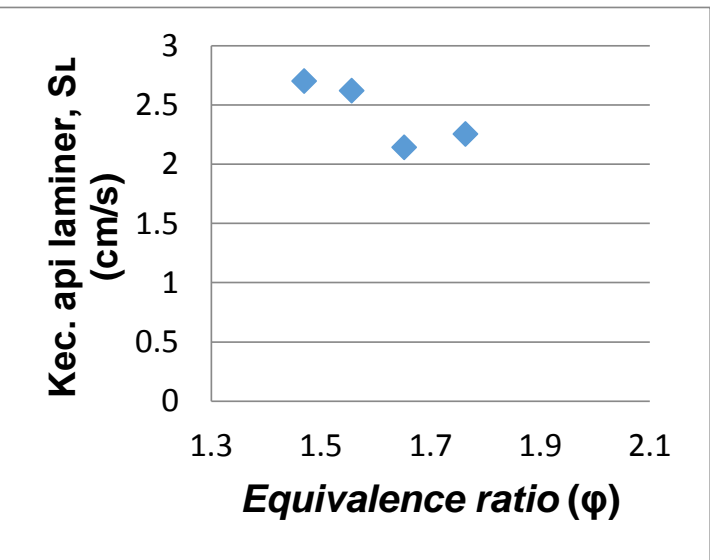

Gambar 4. Equivalence ratio $(\varphi)$ vs kecepatan api laminer (SL) minyak biji kapuk pada api bunsen burner.

Pada gambar 6 ditunjukkan pola api bunsen burner pada minyak kelapa murni dengan variasi equivalence ratio $(\varphi)$ yaitu: $2.00,1.87,1.78$, dan 1.66 pada gambar diatas terlihat semakin kaya udara maka pola api yang terlihat semakin mengecil hingga blow off. Hal ini terjadi karena semakin kaya udara menyebabkan bahan bakar memiliki udara yang berlebih sehingga bahan bakar (fuel) yang terbakar secara difusi semakin berkurang dan menyebabkan pembakaran yang dekat dengan permukaan ujung bunsen burner sehingga tinggi api yang terbentuk semakin pendek hingga terjadi blow off atau padam.

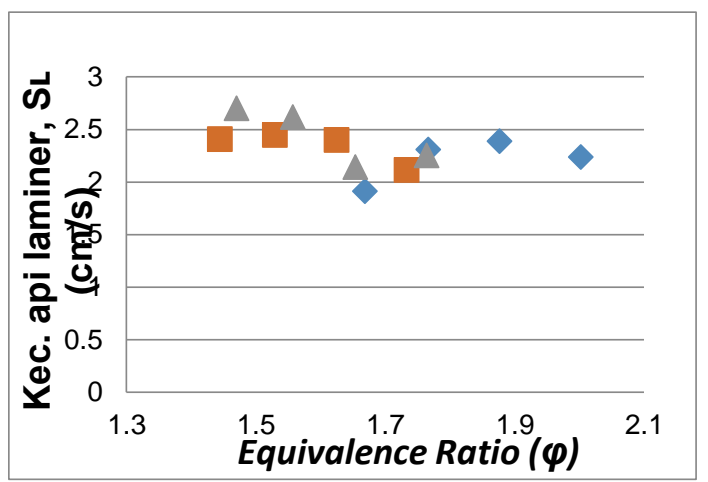

Gambar 5. Equivalence ratio $(\varphi)$ vs kecepatan api laminer (SL) minyak kelapa murni,jarak pagar dan biji kapuk pada api bunsen burner.

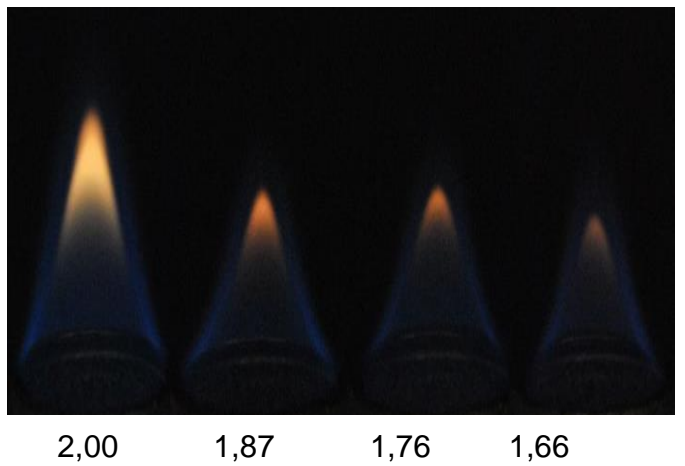

Equivalence ratio $(\varphi)$ pola api bunsen burner

Gambar 6. Pola api bunsen burner minyak kelapa murni.

Pada gambar 7 ditunjukkan pola api bunsen burner pada minyak kelapa murni dengan variasi equivalence ratio $(\varphi)$ yaitu: $1.73,1.62,1.52$, dan 1.44 pada gambar diatas terlihat semakin kaya udara maka pola api yang terlihat semakin mengecil hingga blow off. Hal ini terjadi karena semakin kaya udara menyebabkan bahan bakar memiliki udara yang berlebih sehingga bahan bakar (fuel) yang terbakar secara difusi semakin berkurang dan menyebabkan pembakaran yang dekat dengan permukaan ujung bunsen burner sehingga tinggi api yang terbentuk semakin pendek hingga terjadi blow off atau padam. 


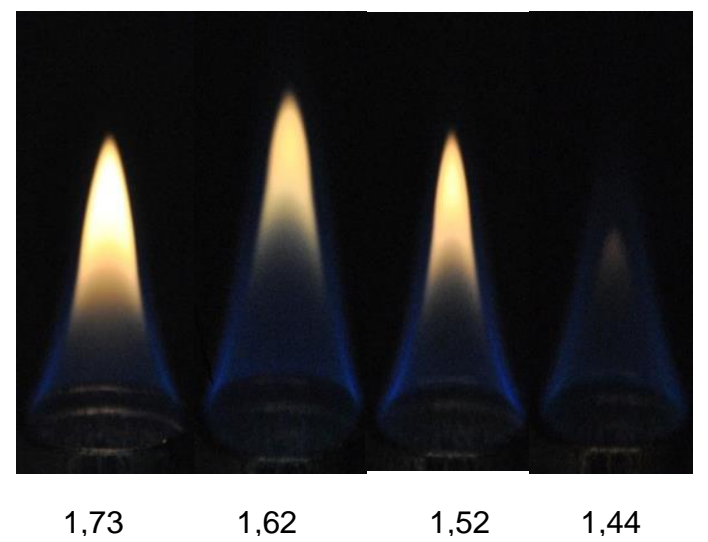

Equivalence ratio $(\varphi)$ pola api bunsen burner

Gambar 7. Pola api bunsen burner minyak jarak pagar

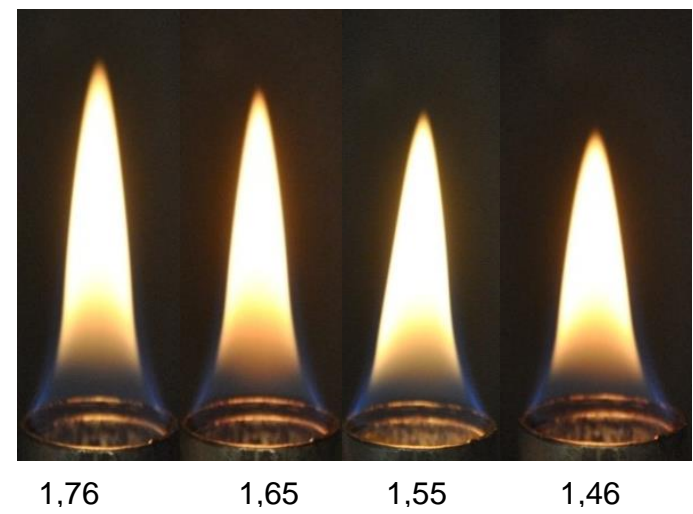

Equivalence ratio $(\varphi)$ pola api bunsen burner

Gambar 8. Pola api bunsen burser minyak biji kapuk

Pada gambar 8 ditunjukkan pola api bunsen burner pada minyak kelapa murni dengan variasi equivalence ratio $(\varphi)$ yaitu: $1.76,1.65,1.55$, dan 1.46 pada gambar diatas terlihat semakin kaya udara maka pola api yang terlihat semakin mengecil hingga blow off. Hal ini terjadi karena semakin kaya udara menyebabkan bahan bakar memiliki udara yang berlebih sehingga bahan bakar (fuel) yang terbakar secara difusi semakain berkurang dan menyebabkan pembakaran yang dekat dengan permukaan ujung bunsen burner sehingga tinggi api yang terbentuk semakin pendek hingga terjadi blow off atau padam.

\section{KESIMPULAN}

Berdasarkan hasil penelitian dan analisis dan pembahasan maka dapat ditarik kesimpulannya sebagai berikut:

1. Pola api bunsen burner minyak kelapa murni, jarak pagar dan biji kapuk dengan equivalence ratio $(\varphi)$ sebagai berikut: (2.00, 1.87, 1.78, 1.66), (1.73, 1.62, 1.52, 1.44) dan (1.76, 1.65, 1.55, 1.46), semakin kaya udara maka pola api yang terlihat semakin mengecil hingga blow off. Hal ini terjadi karena semakin kaya udara menyebabkan bahan bakar memiliki udara yang berlebih sehingga bahan bakar (fuel) yang terbakar secara difusi semakin berkurang dan menyebabkan pembakaran yang dekat dengan permukaan ujung nosel bunsen burner sehingga tinggi api yang terbentuk semakin pendek hingga terjadi blow off atau padam.

\section{DAFTAR PUSTAKA}

[1] Angga., 2013. Pengaruh variasi equivalence ratio $(\varphi)$ terhadap karakteristik api pembakaran premixed minyak jarak pagar pada burner

[2] Arvind Jatoliya.,B.Pandian and Vasudevan Raghavan., 2012. Experimental study of pre-mixed flames on a multi-hole matrix burner.Internasional journal of integreted engineering, vol.4 no.1 p. $1-5$

[3] Bayu., 2013. Pengaruh variasi air fuel ratio (AFR) terhadap karakteristik api pembakaran premixed minyak biji kapuk pada burner

[4] Dharma., 2013. Pengaruh variasi equivalence ratio terhadap karakteristik api pembakaran premixed minyak jarak pagar pada perforated burner

[5] Groff E.G., 1982. The cellular nature of confined spherical propape-air flame,combustion and flame.48:5162.

[6] Heravi., et al, 2007. Kecepatan api 
laminer dan ketebalan api dihitung dengan menggunakan Chemkin (kode premix) untuk rasio kesetaraan 0.5-1.6 dengan dua metode

[7] Irvin Glassman and Richard A. Yetter.,2008. Combustion, academic press, elsevier,California USA

[8] Julie and Cox., 2008. Measurement of laminer burning velocity of methanair mixtures using a slot and bunsen burner

[9] Jerzembeck., et al, 2009. Pengukuran kecepatan pembakaran laminer dengan metode ledakan bejana tertutup untuk bahan bakar campuran-udara pada temperatur $373 \mathrm{~K}$ dan 20 bar

[10]Konnov., 2010. Kecepatan nyala laminer dari etanol dan udara pada suhu ruang dan dipanaskan

[11]Kurniawan., 2006. Kecepatan aliran udara maka proses terjadinya liftoff

[12]Mazlan Abdul Wahid, Khalid M.Saqr, Mohsin M.Sies and Haffis Ujir., 2009. Diffusive thermal instabilities of $\mathrm{C}_{4} \mathrm{H}_{10}-\mathrm{C}_{3} \mathrm{H}_{8}$ /air laminer premixed flames difusion fundamentals. Org, 9 (8), 1-8

[13]Min J.,Baillot F.,Guo H.,Domingues E., Talbaut M.,Patte-Rouland B., 2011. Impact of CO.N or Ar diluted in air on the length and lifting behavior of a laminer diffusion flame, Proceedings of combustion and flame institute 33:1071-1078

[14]Rizki., 2013. Pengaruh kecepatan reaktan terhadap Air Fuel Ratio (AFR) dan karakteristik api pada pembakaran premixed minyak kelapa pada burner.

[15]Ray J.,Najm H.N., Milne R.B., Devine K.D. and Kempka S., 2000. Tripple flame structure and dynamics at the stabilization point of an unsteady lifted jet diffusion flame, Proccedings of the combustion institute 28:219226.

[16]Sahoo P.K., Das L.M., 2009. Combustion analysis of jatropha, karanca and polanga based biodiesel as fuel in a diesel engine,
Fuel 88:994-999

[17]Sidqi., 2011. Menginjeksikan uap minyak kapuk kedalam microcombustor dengan temperatur bervariasi

[18]Takahasi dan Tanoue., 2006. Kecepatan nyala laminer dari etanol, n-heptana, iso-oktana dicampur udara

[19]Tim Sekretariat MAPI-2006. Minyak kelapa sebagai bahan bakar alternatif (biofuel dan biodiesel dari kelapa)

[20]Turns., 1996. An introdction to combustion concepts and applications. Mc graw hills boston: propulsion engineering research center and departement of mechanical and nuclear engineering the Pennsylvania State University

[21]Takahasi., et al. 1990. Lifting Criteria of Jet Diffusion Flame

[22]Uwar., 2012. Pengaruh air fuel ratio (AFR) $\mathrm{CH}_{4}$ dengan penambahan $\mathrm{CO}_{2}$ terhadap laju rambat api pada model Helle shaw cell

[23]Wirawan, I.N.G.Wardana, Rudy Soenoko and Slamet Wahyudi., 2013. Premixed combustion of coconut oil on perforated burner.Internasional jounal of renewable energi development 2 (3) 2013 .,133-139

[24]Wirawan., 2014. Pembakaran premixed minyak nabati pada perforated burner

[25]Wardana I.N.G., 2008. Bahan bakar dan teknologi pembakaran malang PT.Danar Wijaya Brawijaya University Press

[26]Wardanal.N.G.,2010. Combustion charac- teristics of jatropa oil droplet at various oil temperatures. Fuel 89,659-664

[27]Yuan W., Hansen A.C., Zhang Q., 2005. Vapor pressure and normal boiling point predictions for pure methyl esters and biodiesel fuels, Fuel 84:943-950. 